\title{
Problem Based Learning: An Experience of B.P. Koirala Institute of Health Sciences, Nepal
}

\author{
Baral $\mathrm{P}^{*}$, Koirala $\mathrm{S}^{2}$, Shrestha $\mathrm{S}^{2}$, Shah $\mathrm{S}^{2}$, Kumar $\mathrm{S}^{3}$, Baidya $\mathrm{R}^{3}$ \\ ${ }^{1}$ Professor, Anatomy Department, Gandaki Medical College \& Teaching Hospital, Pokhara, Nepal \\ ${ }^{2}$ Associate Professor, Anatomy Department, B.P.Koirala Institute of Health Sciences, Dharan, Nepal \\ ${ }^{3}$ Assistant professor of anatomy, Weill Cornell Medicine, New York, USA
}

\author{
Keywords \\ Attitude, Medical education, \\ Problem-based learning, Students. \\ Corresponding author \\ ${ }^{*}$ Dr. Prakash Baral, Professor \\ Anatomy department \\ Gandaki Medical College, Pokhara \\ Email: prakashbaral2002@gmail.com
}

\begin{abstract}
Introduction: Problem-based learning (PBL) is a kind of teaching-learning method in which students' role is prime and they learn about a subject by active participation in problem solving.

Methods: A total of 96 students studying in second year MBBS program were enrolled into present study. A questionnaire was given to students and they were asked to choose the option they felt about PBL methods. The questionnaire comprised of ten likert items out of which three were negative and seven were positive items.

Results: Mean score for each statement in the questionnaire and the overall mean score were calculated. Overall mean score was 3.47.

Conclusions: It was concluded that students of second year MBBS at BPKIHS, had a positive attitude towards PBL method of teaching-learning activity.
\end{abstract}

\section{INTRODUCTION}

Problem-based learning (PBL) is a learning method in which students' role is prime and they learn about a subject by active participation in problem solving.

They develop collaboration skills among colleagues, intrinsic motivation and self directed learning effectively ${ }^{1}$. There is active transfer of knowledge from teacher to student in PBL. The tutor's role is important in facilitating learning by being as the guide, supporting and monitoring the learning process ${ }^{2}$. PBL differs from the traditional learning methods which were more lecture based ${ }^{3}$.

To conduct PBL, students are divided into smaller groups. Each group contains six to eight students. One facilitator is appointed for the group. Usually junior faculty or residents are appointed as facilitator or tutor. The facilitator or tutor monitors or supervises the PBL.
Medical problems (triggers) inform of case history (patient's complaint, history of present illness, required personal, medical, family history) physical and systemic examination, investigation results are provided to students. Students discuss and interact themselves in PBL session. Students are suggested to consult standard textbooks for searching the information they deem needful but the facilitator or tutor does not teach them in PBL session. The session lasts two hours in a day. Following dealing all the problems or triggers from a chapter, students present a seminar.

\section{Rationale for the study}

B. P. Koirala Institute of Health Sciences (BPKIHS) of Nepal is running the PBL program for MBBS since18 years but so far what was the attitude MBBS students toward it had not been assessed; thus the study was undertaken. 


\section{METHODS}

One hundred students studying in the second year MBBS program were enrolled into research study. Four students were absent on the day of the study so total number of subjects for the study was 96. A questionnaire with 10 likert items was given to students and they were asked to choose the option as they felt right about PBL methods. Students were asked not to disclose their name so that actual or realistic information could be obtained for the study.

The questionnaire comprised of ten likert items out of which three were negative and seven were positive items.

Table 1: Questionnaire

1 PBL is effective in stimulating students for self-directed learning
a. Strongly agree
b. Agree
c. Can't say
d. Disagree
e. Strongly disagree

2 PBL is a better way of learning method
a. Strongly agree
b. Agree
c. Can't say
d. Disagree
e. Strongly disagree

3 PBL classes are interesting sessions at BPKIHS
a. Strongly agree
b. Agree
c. Can't say
d. Disagree
e. Strongly disagree

4 PBL involves all students in interaction and discussion thus every student enjoys learning
a. Strongly agree
b. Agree
c. Can't say
d. Disagree
e. Strongly disagree

$5 \quad$ PBL induces thirst for knowledge
a. Strongly agree
b. Agree
c. Can't say
d. Disagree
e. Strongly disagree

6 PBL is not useful for understanding the subject

a. Strongly agree

b. Agree

c. Can't say

d. Disagree

e. Strongly disagree

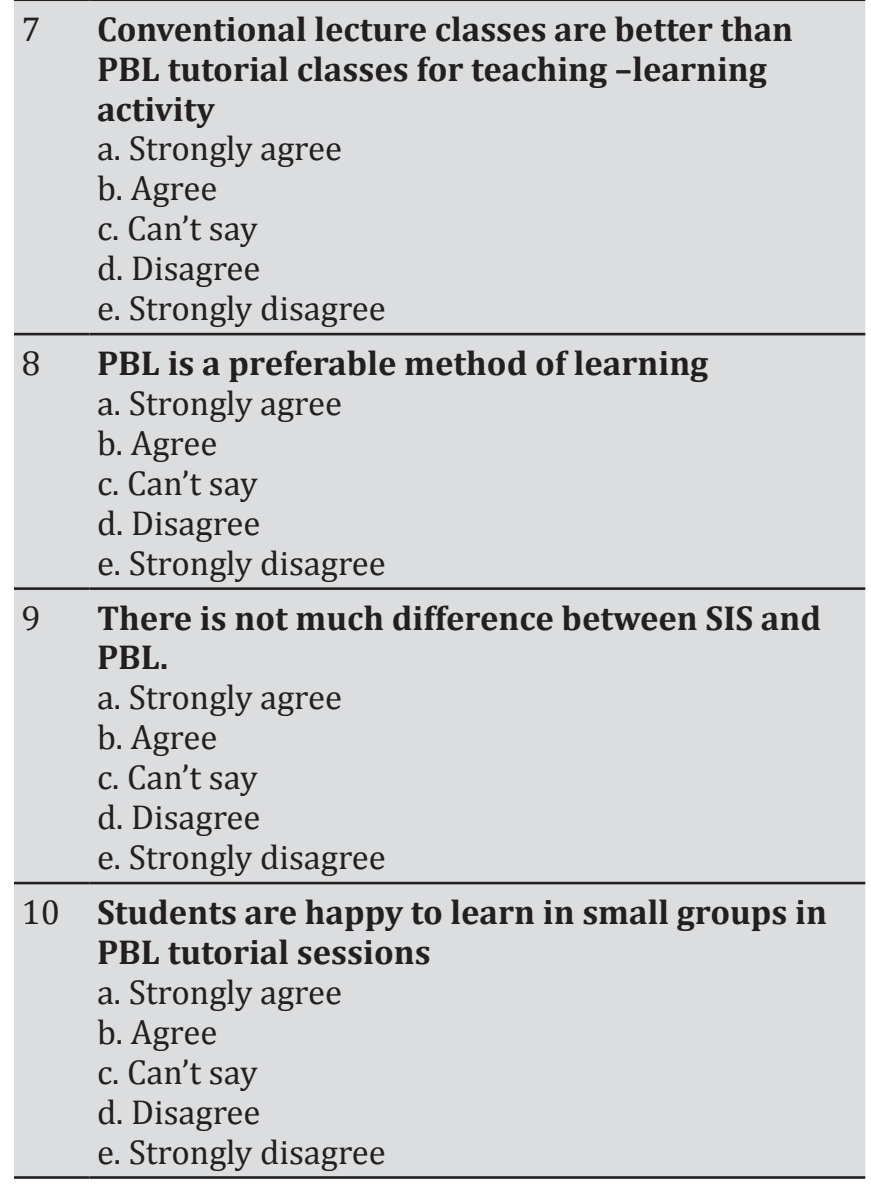

\section{Analysis}

Mean score for each statement in the questionnaire and the overall mean score were calculated.

After receiving the completed questionnaire sheets from the students the score was given for each statement as follows:

For negative item statements like 6, 7 and 9, score $1=$ for strongly agree; 2 = agree; 3 = can't say; 4 = disagree; 5 = strongly disagree

For positive item statements like 1, 2, 3, 4, 5, 8 and 10, score 5 = for strongly agree; 4 = agree; 3 = can't say; 2 = disagree; 1 = strongly disagree.

Out of the ten questions in the questionnaire, seven questions $(1,2,3,4,5,8,10)$ were positive statements which were scored from 1 to 5 and, score $5=$ for strongly agree; 4 =agree; 3 = can't say; 2 = disagree; 1 = strongly disagree.

\section{RESULTS}

The mean score for these questions is as follows 
Fig 1: Mean scores of responses for all the positive statements

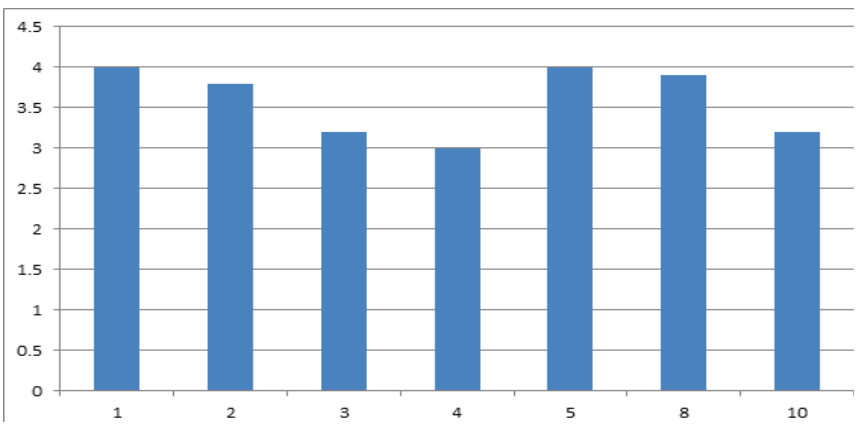

This figure shows that most responses are in agreement towards the benefit of PBL, since the mean score of most questions is more than 3 which is an equivocal response.

Table 2: Average of all the mean scores for positive statements

\begin{tabular}{cc}
\hline Question no & Mean score \\
\hline 1 & 4.0 \\
2 & 3.8 \\
3 & 3.2 \\
4 & 3.0 \\
5 & 4.0 \\
8 & 3.9 \\
10 & 3.2 \\
Average score & 3.59 \\
\hline
\end{tabular}

Average score for all the positive statements $=3.59$ which is inclining more towards a positive attitude of the students towards problem based learning.

Response to the negative statements: Questions 6, 7, 9 are negative statements which were scored from 1 to 5 , score $1=$ strongly agree; 2 = agree; 3 = can't say; $4=$ disagree; 5 = strongly disagree

Fig 2: Mean scores for the negative statements

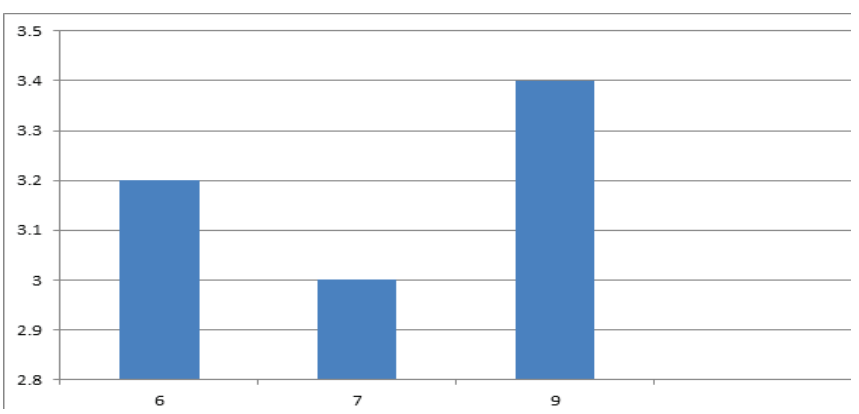

The mean score for all the responses to the negative statements are in disagreement with the claim that PBL is not helpful, hence there is conclusive evidence that majority of the students have a explicitly good attitude towards PBL

Table 3: Average score for negative statements

\begin{tabular}{cc}
\hline Question no: & Mean score \\
\hline 6 & 3.2 \\
7 & 3.0 \\
9 & 3.4 \\
Average score: & 3.2 \\
\hline
\end{tabular}

Average score for the responses for the negative statements $=3.2$, which is a score indicating the positive influence of PBL.

Lastly the mean score for each statement was calculated which is as follows:

Table 4: Mean score for each statement

\begin{tabular}{|c|c|c|}
\hline Sl No & Statements & $\begin{array}{l}\text { Mean } \\
\text { score }\end{array}$ \\
\hline 1. & $\begin{array}{l}\text { PBL is effective in stimulating students } \\
\text { for self-directed learning }\end{array}$ & 4.0 \\
\hline 2. & PBL is a better way of learning method & 3.8 \\
\hline 3. & $\begin{array}{l}\text { PBL classes are interesting sessions at } \\
\text { BPKIHS }\end{array}$ & 3.2 \\
\hline 4. & $\begin{array}{l}\text { PBL involves all students in interaction } \\
\text { and discussion thus every student en- } \\
\text { joys learning }\end{array}$ & 3.0 \\
\hline 5. & PBL induces thirst for knowledge & 4.0 \\
\hline 6. & $\begin{array}{l}\text { PBL is not useful for understanding the } \\
\text { subject }\end{array}$ & 3.2 \\
\hline 7. & $\begin{array}{l}\text { Conventional lecture classes are better } \\
\text { than PBL tutorial classes for teaching- } \\
\text { learning activity }\end{array}$ & 3.0 \\
\hline 8. & PBL is a preferable method of learning & 3.9 \\
\hline 9. & $\begin{array}{l}\text { There is not much difference between } \\
\text { SIS and PBL }\end{array}$ & 3.4 \\
\hline 10. & $\begin{array}{l}\text { Students are happy to learn in small } \\
\text { groups in PBL tutorial sessions }\end{array}$ & 3.2 \\
\hline & Over all mean score & 3.47 \\
\hline
\end{tabular}

Overall mean score was 3.47 which suggested that students had a positive attitude towards PBL method of teaching-learning activity.

\section{DISCUSSION}

BPKIHS follows the Barrows' PBL model where in students are active in learning, learning in small student groups, ideally consisting of 6-10 students, and tutors or facilitators to guide the students rather than teaching ${ }^{4,5}$. 
The response acquired from the students at BPKIHS has been a positive one towards the benefits that can be procured from adopting PBL. The average of the scores for the positive statements was 3.59 and out of the seven positive statements in the questionnaire, all the questions had a mean score of 3.59 or more which is a response in agreement to the benefits of PBL. The average score for the negative statement in the questionnaire was 3.2 and out of the three questions, the responses generated to all three were three or more which is in disagreement to the statements that PBL may not be beneficial. Overall mean score was 3.47 which suggested that students had a positive attitude towards PBL method of teachinglearning activity.

The present study conducted at BPKIHS proved that this learning method is well accepted by students as it enhances their power of critical thinking ${ }^{6,7}$. The another study also found that teaching methods based on inquiry greatly reduced the achievement gap (underachievement) ${ }^{8}$.

In line with BPKIHS findings a systematic review of the effects of PBL has found communication skills and coping with uncertainties are enhanced. Research resulting from 10 years of data from the University of Missouri, School of Medicine showed that PBL has a positive effect on the students' competency ${ }^{9}$.

BPKIHS has similar experience with another study from Sloveniathat students who were exposed to PBL were better at solving more difficult problems, however, no significant difference was found with regard to their attitude regarding mathematics ${ }^{10}$.

Like BPKIHS other universities have also successfully implemented and benefited from adopting PBL as a prime method in their teaching programs to enhance learning. Monash University, Maastricht University, Lake Erie and Libyan University were among the many who successfully implemented this technique as a prime teaching modality. More than $80 \%$ of all the medical schools in the United States currently have some form of PBL in their respective programs ${ }^{9}$.

\section{CONCLUSIONS}

Overall mean score of 3.47 suggested that the students of second year MBBS at BPKIHS had a positive attitude towards PBL method of teaching-learning activity. Thus this type of teaching-learning method is preferable to students.

\section{REFERENCES}

1. Hmelo-Silver, Cindy E. Problem-based learning: What and how do students learn? Educational Psychology Review. 2004; 16 (3): 235-266.

2. Schmidt, Henk G, Rotgans, Jerome I, Yew, Elaine HJ. The process of problem-based learning: What works and why. MedicalEducation. 45 (8): 792-806. doi:10.1111/ j.1365-2923.2011.04035.x.http://onlinelibrary. wiley.com/doi/10.1111/j.1365-2923.2011.04035.x/ abstract. Retrieved 16 November 2012.

3. Hung, Woei. Theory to reality: A few issues in implementing problem-based learning. Educational Technology Research and Development. 2011; 59 (4): 529-552.

4. Barrows, Howard S. Problem-based learning in medicine and beyond: A brief overview. New Directions for Teaching and Learning. 1996; 68: 3-12.

5. Neville AJ. Problem-based learning and medical education forty years on. A review of its effects on knowledge and clinical performance. Medical principles and practice: International Journal of the Kuwait University Health Science Centre. 2009; 18 (1): 1-9.

6. Barrett, Terry. The problem-based learning process as finding and being in flow. 2010; 47 (2): 165-174.

7. Wells SH, Warelow PJ, Jackson KL. Problem based learning (PBL): A conundrum. Contemporary Nurse. 2009; 33(2): 191-201.

8. Hmelo-Silver, Cindy E, Duncan, Ravit Golan, Chinn, Clark A. Scaffolding and achievement in problembased and inquiry learning: A response to Kirschner, Sweller, and Clark. Educational Psychologist. 2006; 42 (2): 99-107.

9. Koh GC, Khoo HE, Wong ML, Koh D. The effects of problem-based learning during medical school on physician competency: A systematic review. CMAJ. 2008; 178 (1): 34-41.

10. Cotič, Mara; Zuljan, Milena Valenčič. Problem-based instruction in mathematics and its impact on the cognitive results of the students and on affectivemotivational aspects. Educational Studies. 2009; 35 (3): 297-310. 